\title{
ПРОИЗВОДНЫЕ 5-ФЕНИЛТЕТРАЗОЛ-2-ИЛУКСУСНОЙ КИСЛОТЫ КАК КЛЮЧЕВЫЕ РЕАГЕНТЫ В СИНТЕЗЕ БИОЛОГИЧЕСКИ АКТИВНЫХ ВЕЩЕСТВ, ПРОЯВЛЯЮЩИХ ПРОТИВООПУХОЛЕВУЮ АКТИВНОСТЬ
}

\author{
О.В. Миколайчук' \\ В.А. Островский ${ }^{3}$, А.А. Богданова ${ }^{3}$, Ю.Н. Павлюкова ${ }^{3}$, Н.Т. Шманёва \\ Ю.А. Нащекина ${ }^{4}$, В.В. Шаройко, ${ }^{1,2}$ К.Н. Семенов,
}

${ }^{1}$ Санкт-Петербургский государственный университет, 199034, Россия, Санкт-Петербург, Университетская наб., д. 7-9.

2Первый Санкт-Петербургский государственный медицинский университет им. акад. И.П. Павлова, 197022, Россия, Санкт-Петербург, ул. Льва Толстого, д. 6-8. ${ }^{3}$ Санкт-Петербургский государственный технологический институт (технический

университет), 190013, Россия, Санкт-Петербург, Московский проспект, д. 26.

${ }^{4}$ Институт цитологии РАН, 194064, Россия, Санкт-Петербург, Тихорецкий пр., д. 4.

DOI: 10.19163/MedChemRussia2021-2021-479

E-mail: st801293@spbu.ru

Тетразольный цикл является важнейшим фармакофорным фрагментом и входит в структуру многих активных фармацевтических субстанций современных лекарственных средств [1,2]. Нами показано, что тетразолилуксусные кислоты и их производные можно рассматривать как перспективные реагенты направленного синтеза биологически активных веществ, проявляющих противоопухолевую активность. В данной работе 5-фенилтетразол2-илуксусная кислота была использована в конвергентных схемах синтеза новых неаннелированных гибридных гетероциклических систем $(1,2)$, которые, по данным компьютерного (3D-QSAR) прогноза, подтвержденным результатами in vitro исследований, проявляют свойства ингибиторов роста неоплазий.

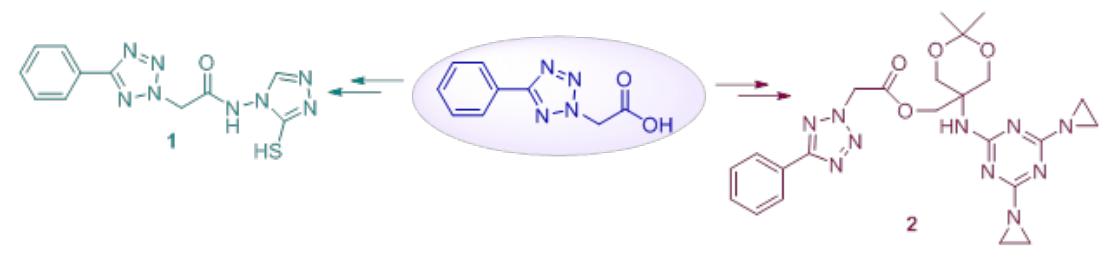

Исследования противоопухолевой активности in vitro показали, что полученные соединения проявляют выраженную дозозависимую цитотоксичность в отношении клеточных линий глиобластомы человека (T98G) и аденокарциномы печени человека (SK-HEP-1), начиная с концентрации 100 мкМ для соединения 1 и 50 мкМ для соединения 2. Методом МТТ теста были определены значения IC ${ }_{50}$ для T98G - 49.3 мкM (1), 66.43 мкM (2); для SK-HEP-1 -53.6 мкM (1), 62.8 мкM (2).

Работа выполнена при финансовой поддержке РФФИ (25-53-05010 Arm_a; 21-515-10007 KO_a).

\section{Литература}

[1] Островский В.А., Трифонов Р.Е. Попова Е.А. Изв. АН. Сер. хим. 2012, 4, 765-777.

[2] Попова Е.А., Трифонов Р.Е., Островский В.А. Успехи химии. 2019, 88, 6, 644-676. 